\title{
CHARACTERISATION OF LIGNIN EXTRACTED FROM SIX MANGROVE SPECIES GROWN IN BANGLADESH
}

\author{
M. SARWAR JAHAN*, A. AL-MARUF, ${ }^{*}$ M. AMINUL AHSAN ${ }^{* * *}$ and SUNG PHIL MUN*** \\ "Pulp and Paper Research Division, BCSIR Laboratories, Dr. Qudrat-i-Khuda Road, \\ Dhaka 1205, Bangladesh \\ **INARS, BCSIR, Dr. Qudrat-i-Khuda Road, Dhaka 1205, Bangladesh \\ ${ }^{* * *}$ College of Agriculture and Life Sciences, Chonbuk National University, Jeonju, \\ Jeonbuk 561-756, Korea \\ \Corresponding author: M. Sarwar Jahan, sarwar2065@hotmail.com
}

Received May 18, 2018

Lignin from six mangrove species [namely, keora (Sonneratia apetala), gewa (Excoecaria agallocha), bine (Avicennia alba), sundri (Heritiera fomes), pashur (Xyloccarpous mekongests) and kakra (Bruguiera gymnorhiza)] was extracted by acidic dioxane. The isolated lignin was submitted to structural characterization employing spectroscopic techniques (FTIR, ${ }^{1} \mathrm{H}-\mathrm{NMR}$ ), as well as elemental analysis, molecular weight and methoxyl content determination. Results showed that the lignin of these mangrove species was mainly of the syringyl type $(\mathrm{S})$, followed by the guaiacyl type $(\mathrm{G})$. The polydispersity of the mangrove species lignin was very high. NMR spectra showed that the erythro protons (H $\alpha)$ give a stronger peak at $6.01 \mathrm{ppm}$ than the corresponding peak for the threo form at $6.09 \mathrm{ppm}$ in bine, gewa, kakra and sundari lignins, while keora lignin showed almost equal intensity.

Keywords: dioxane lignin, erythro form, guaiacyl unit, mangrove species, molecular weight, syringyl unit

\section{INTRODUCTION}

Mangrove forests play an important role in stabilizing the shoreline and reducing the distressing impact of natural disasters, such as cyclones, tsunamis and hurricanes. Mangrove forests provide breeding and nursing grounds for marine and pelagic species, while also supplying food, medicine, fuel and building materials for local people. The Sundarbans mangrove forest offers coastal protection to millions of people in Bangladesh and India. Currently, the Sundarbans covers approximately $10,000 \mathrm{~km}^{2}, 40 \%$ of which is in India and the rest is in Bangladesh. ${ }^{1}$ The Sundarbans is a unique and the largest contiguous natural mangrove forest in the world. It is situated in the southern part of Satkhira, Khulna and Bagerhat districts, the south-western region of Bangladesh. It has an area of about 601,700 hectares, which represents $4.13 \%$ of the country and $38.12 \%$ of the state forest land. Sundri (Heritiera fomes) is the characteristic species of the freshwater zone of the Sundarbans. The forest of the moderately saltwater zone is a mixture of gewa (Excoecaria agallocha) and sundry, with varying amounts of goran (Ceriops decandra) and other species. The forest in the saltwater zone is dominated by goran (Ceriops decandra), gewa (Excoecaria agallocha), passur (Xylocarpus mekongensis) and dhandal (Xylocarpus granatum).

In addition to the Sundarbans, plantations along the shore of the coastal districts of Bangladesh commenced in 1961-62 to protect lives and properties from natural calamities, such as cyclones and tidal bores, and to stabilize the newly accreted lands. This initiative has gained momentum since 1980-81 with the aid of development partners, and afforestation programs have been extended over the foreshore islands, embankments and along the open coast. Sonneratia apetala and Avicennia officinalis are the main species of the coastal plantation. The mangrove plantations in the coastal area have reached 196,000 ha.

For industrial application, thorough knowledge of these species is needed. Although the chemistry of mangrove wood has not been studied yet as extensively as that of most other wood species, preliminary investigations of the 
chemical constituents have led to the possibility of several new applications. Very little information is available on the chemical composition of mangrove species. Mansyur et al. ${ }^{2}$ studied the chemical composition of various species of mangrove woods and showed variation in lignin and pentosans contents and in solubility. Miles et $a l^{3}$ investigated the chemical constituents (such as salts, organic acids, carbohydrates, hydrocarbons, benzoquinone, naphthofurans, sesquiterpenes, triterpenes, alkaloids, flavonoids, polymers, sulfur derivatives and tannins) of mangrove plants and their potential application in medicine and agriculture. Singh et al. ${ }^{4}$ explored chemi-mechanical pulping by the cold soda process of different mangrove wood chips, such as Heritiera littoralis, Bruguieva conjugata and Rhizophora mucronata. They obtained pulps with $75-84 \%$ screened yield, with strength properties higher than those of mechanical pulps obtained from the same species. For the first time, Mun et al. ${ }^{5}$ comprehensively studied the chemical constituents of six mangrove species. This research group also showed the pulping potential of these six mangrove species and recommended them for packaging grade paper. $^{6}$

Lignin is a phenyl-propanoid $\left(\mathrm{C}_{9}\right)$ polyphenol, mainly linked by carbon-carbon bonds and arylglycerol ether bonds between the monomeric phenolic p-coumaryl $(\mathrm{H})$, coniferyl $(\mathrm{G})$ and sinapyl alcohol (S) units. Isolation techniques of lignin from softwood and hardwood are available and its chemistry being much better known. ${ }^{7}$ Lignin from hardwood, softwood and non-wood has been studied by numerous researchers. ${ }^{8-10}$ Evtuguin et al. ${ }^{11}$ conducted studies on plantation Eucalyptus globulus lignin and found it to be of the $S / G$ type, with an extremely high proportion of syringyl $(S)$ units $(82-86 \%)$ and a minor proportion of $p$-hydrophenyl propane $(H)$ units. Oliveira et al. ${ }^{12}$ showed that banana plant leaf sheath lignin was of the HGS type, with a molar proportion of p-hydroxyphenyl (H)/guaiacyl $(\mathrm{G}) /$ syringyl (S) units of 12:25:63. Most of the $\mathrm{H}$ units in lignin are terminal phenolic coumarates linked to other lignin substructures by benzyl and $\mathrm{C} \gamma$-ester bonds, in contrast to ferulates, which are mainly ether linked to bulk lignin. Hardwood lignin from the tropical region was demonstrated to have lower content of alcoholic and phenolic hydroxyl groups than temperate hardwood lignin. ${ }^{13-15}$ However, no study has been found on the lignin chemistry of mangrove species. The objective of this study was to isolate lignin from six mangrove species grown in the Sundabans by the acidic dioxane method. Isolated lignins were characterized by FTIR and ${ }^{1} \mathrm{H}-\mathrm{NMR}$ spectroscopy, alkaline nitrobenzene oxidation, molecular weight determination, as well as elemental and methoxyl analyses.

\section{EXPERIMENTAL}

\section{Raw materials}

Wood chips of six mangrove species, namely, keora (Sonneratia apetala), gewa (Excoecaria agallocha), bine (Avicennia alba), sundri (Heritiera fomes) pashur (Xyloccarpous mekongests) and kakra (Bruguiera gymnorhiza), were ground (40/60 mesh) separately in a Wiley mill, extracted with alcoholtoluene solvent and dried in vacuum over $\mathrm{P}_{2} \mathrm{O}_{5}$.

\section{Isolation of lignin}

The extract free wood meals were refluxed with acidic dioxane (9:1) solution. The concentration of $\mathrm{HCl}$ in the dioxane solution was adjusted to 0.2 mole/L. The dioxane to wood meal ratio was $8: 1$. The wood meal was refluxed with dioxane solution for about 1 hour in $\mathrm{N}_{2}$ atm. The $\mathrm{N}_{2}$ flow was maintained at $50 \mathrm{~mL} / \mathrm{min}$. After completing the reflux time, the wood meal dioxane mixture was filtered in a Buckner funnel using filter no. 2. The residue was washed with dioxane solution (9:1). The dioxane solution was then neutralized by adding solid $\mathrm{Na}_{2} \mathrm{CO}_{3}$ and filtered. The filtrate was concentrated in a vacuum evaporator at 40 ${ }^{\circ} \mathrm{C}$. Then, concentrated dioxane solution was added dropwise to water to precipitate lignin. The lignin precipitate was washed and dried in vacuum over $\mathrm{P}_{2} \mathrm{O}_{5}$.

Dried crude lignin was dissolved in dioxane $(9: 1)$, and again precipitated in ether with constant stirring by a magnetic bar. The precipitated pure lignin was dried in vacuum over $\mathrm{P}_{2} \mathrm{O}_{5}$ and weighed. The yield of dioxane lignin was calculated based on Klason lignin. The purity of dioxane lignin was determined by measuring Klason lignin.

\section{Elemental analysis}

$\mathrm{C}, \mathrm{H}, \mathrm{O}$ and $\mathrm{N}$ analyses were carried out in an analytical centre at Kyushu University, Japan. The methoxyl content in dioxane lignin was determined in accordance with Japan International Standard Methods (JIS P8013 1972).

\section{Acetylation}

Dioxane lignin $(100 \mathrm{mg})$ was added in $1.5 \mathrm{~mL}$ of dry pyridine - acetic anhydride (1:1) and kept for $72 \mathrm{~h}$. The solution was added to a 10 -fold volume of ice-cold water, whereupon the acetylated sample was recovered as a precipitate, which was purified by successive washing with water and dried under vacuum over $\mathrm{P}_{2} \mathrm{O}_{5}$. 


\section{Molecular weight}

The weight average (Mw) and number average molecular (Mn) weight of acetylated lignins from keora, gewa, bine, sundry, pashur and kakra were determined by GPC on a Sodex KF-802.5 column. The samples were dissolved in tetrahydrofuran (THF) and $10 \mu \mathrm{L}$ was injected. The column was operated at $30^{\circ} \mathrm{C}$ and eluted with THF at a flow rate of $1 \mathrm{~mL} / \mathrm{min}$. The column was calibrated using polystyrene standards.

\section{Spectroscopic analyses}

FTIR: IR spectra were recorded by using a Shimadzu FTIR spectrometer model 8201PC. The dried samples were embedded in $\mathrm{KBr}$ pellets in the concentration of about $1 \mathrm{mg} / 100 \mathrm{mg} \mathrm{KBr}$. The spectra were recorded in the absorption band mode in the range of 4000-400 $\mathrm{cm}^{-1}$.

${ }^{1} \mathrm{H}$ NMR: the spectra of lignin solutions (100 mg of acetylated lignin in $0.5 \mathrm{~mL} \mathrm{CDCl}_{3}$ ) were recorded in a Bruker 400 spectrometer. The solvent was used as internal standard (ppm 7.25). For quantification of protons, the signal in the specified regions of the spectrum were integrated with respect to a spectrumwide baseline drawn at the level of the background noise, and the results were referred to the signal for methoxyl protons, whose average number per $\mathrm{C}_{9}$ unit was established as described above.

\section{RESULTS AND DISCUSSION}

These mangrove species yielded $44.9-56.2 \%$ dioxane lignin (Table 1). The yields were better than in the case of the nalita wood lignins, using the same isolation method. ${ }^{13}$ The acidic isolation conditions employed for the lignin extraction process are believed to result in the hydrolysis of the lignin-carbohydrate complex (LCC) linkages, allowing the release of lignin fragments into the aqueous dioxane solution from nalita wood. ${ }^{16}$ The purity of these lignins was of $85-91 \%$. The yield of the lignin isolated from these six mangrove species was lower than that of other lignocellulosics and annual plants. ${ }^{12,17}$ This can be explained by a strong structural association of in situ lignin with polysaccharides.

\section{Elemental analysis and methoxyl content determination}

Elemental analysis and determination of functional groups are important to understand the chemical structure of isolated lignin. Chemical analyses were conducted on the lignin isolated from different mangrove species, and $\mathrm{C}_{9}$ atoms and group ratios are shown in Table 2. The results show that the lignin from all of these mangrove species had almost similar $\mathrm{C}, \mathrm{H}, \mathrm{N}$ content, but the methoxyl content was the highest in gewa $(22.0 \%)$ and the lowest in sundari (18.6\%). The lignin sample showed a high content of methoxyl groups $\left(1.33-1.63 / \mathrm{C}_{9}\right)$, which was close to that of Eucalyptus globulus wood. ${ }^{11}$ Nitrogen was mainly derived from the protein-lignin complexes formed during delignification. The methoxyl content in these mangrove species was higher than that of other hardwood species. ${ }^{18}$

\section{FTIR spectra}

The band at $1328 \mathrm{~cm}^{-1}$ is associated with the $\mathrm{C}=\mathrm{O}$ stretching of the syringyl structure in lignin molecules, whereas the band at $1030 \mathrm{~cm}^{-1}$, which is characteristic of primary alcohol, ${ }^{19}$ is found in all the mangrove species lignins. Strong bands at 1330, 1220 and $1120 \mathrm{~cm}^{-1}$ corresponding to the syringyl unit are found in all the lignins, whereas a small shoulder or none at all corresponding to the guaiacyl unit was found at 1275, 1153 and $1037 \mathrm{~cm}^{-1} .{ }^{20}$ These results are consistent with the findings reported for alkaline nitrobenzene oxidation. ${ }^{5}$ The vibrations attributable to the aromatic rings are found at 1600 and $1510 \mathrm{~cm}^{-1}$. A weak band at 1725 and $1650 \mathrm{~cm}^{-1}$, due to either the acetyl or the uronic ester groups, were observed in all the mangrove species ${ }^{21}$ which indicated that the isolated lignin presented minor carbohydrate impurities.

Table 1

Lignin yields for six mangrove species

\begin{tabular}{lc}
\hline Sample & Lignin yield, \% (based on Klason lignin) \\
\hline Sundari & 49.8 \\
Bine & 44.9 \\
Keora & 56.2 \\
Gewa & 47.6 \\
Kakra & 48.3 \\
Pashur & 55.5 \\
\hline
\end{tabular}


M. SARWAR JAHAN et al.

Table 2

Elemental analysis and methoxyl content of six mangrove species lignins

\begin{tabular}{|c|c|c|c|c|c|c|}
\hline \multirow{2}{*}{ Sample } & \multicolumn{5}{|c|}{ Percentage (\%) } & \multirow{2}{*}{$\mathrm{C}_{9}$ formula $^{*}$} \\
\hline & $\mathrm{C}$ & $\mathrm{H}$ & $\mathrm{N}$ & $\mathrm{O}$ & $\mathrm{OCH}_{3}$ & \\
\hline Sundari & 55.97 & 5.45 & 0.38 & 38.20 & 18.6 & $\mathrm{C}_{9} \mathrm{H}_{8.09} \mathrm{O}_{5.72}\left(\mathrm{OCH}_{3}\right)_{1.33}$ \\
\hline Bine & 55.62 & 5.98 & 0.26 & 38.14 & 21.7 & $\mathrm{C}_{9} \mathrm{H}_{8.88} \mathrm{O}_{5.67}\left(\mathrm{OCH}_{3}\right)_{1.60}$ \\
\hline Keora & 57.60 & 5.97 & 0.30 & 36.13 & 20.7 & $\mathrm{C}_{9} \mathrm{H}_{8.64} \mathrm{O}_{5.10}\left(\mathrm{OCH}_{3}\right)_{1.45}$ \\
\hline Gewa & 55.34 & 6.00 & 0.18 & 38.48 & 22.0 & $\mathrm{C}_{9} \mathrm{H}_{8.93} \mathrm{O}_{5.67}\left(\mathrm{OCH}_{3}\right)_{1.63}$ \\
\hline Kakra & 56.35 & 6.00 & 0.16 & 37.49 & 20.8 & $\mathrm{C}_{9} \mathrm{H}_{8.92} \mathrm{O}_{5.49}\left(\mathrm{OCH}_{3}\right)_{1.50}$ \\
\hline Pashur & 55.18 & 6.00 & 0.26 & 38.56 & 21.8 & $\mathrm{C}_{9} \mathrm{H}_{8.88} \mathrm{O}_{5.80}\left(\mathrm{OCH}_{3}\right)_{1.62}$ \\
\hline
\end{tabular}

"Empirical formula $\mathrm{C}_{\mathrm{x}} \mathrm{H}_{\mathrm{y}} \mathrm{O}_{\mathrm{z}}\left(\mathrm{OCH}_{3}\right)_{\mathrm{n}}$ was calculated as follows: $\mathrm{n}=\left(\% \mathrm{OCH}_{3}\right) / 31.04 ; \mathrm{x}=(\% \mathrm{C}) / 12-\mathrm{n}$; $\mathrm{y}=(\% \mathrm{H})-3 \mathrm{n} ; \mathrm{z}=(\% \mathrm{O}) / 16-\mathrm{n}$

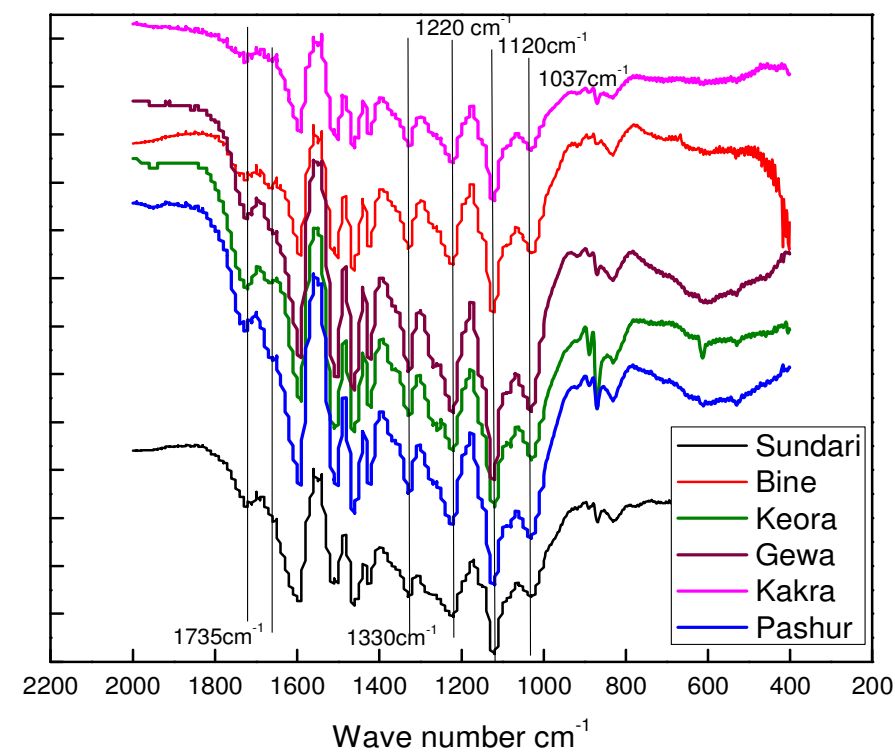

Figure 1: FT-IR spectra of six mangrove species lignins

The bands at around $1735 \mathrm{~cm}^{-1}$ and at 1370 $\mathrm{cm}^{-1}$ are due to the presence of acetyl groups. ${ }^{22} \mathrm{~A}$ strong absorbance at $1737 \mathrm{~cm}^{-1}$ is assigned to $\mathrm{C}=\mathrm{O}$ in unconjugated ketones, carbonyls and ester groups. $^{20}$

The ratio of $A_{1462} / A_{1595}$, related to the amounts of methoxyl groups in lignins, ${ }^{22}$ also indicated the presence of a higher $\mathrm{S} / \mathrm{V}$ ratio. This result is consistent with that of our previous communication, where the alkali $\mathrm{S} / \mathrm{V}$ ratio of 1.64.0 was obtained by alkaline nitrobenzene oxidation from these six mangrove species. ${ }^{5}$

\section{Molecular weight}

The weight average $(\mathrm{Mw})$ and number average (Mn) molecular weight, as well as the polydispersity of the lignin from the different mangrove species were computed from their chromatograms and are shown in Table 3. The weight average molecular weight $(\mathrm{Mw})$ of the six mangrove species was found to be 4400-11600. The data shows that the Mw of bine lignin was the highest among these six mangrove species. The Mw of softwood lignins seems to be of the order of 20000, whereas lower values have been reported for hardwood lignin. ${ }^{23}$ According to Pouteau, ${ }^{24}$ low molecular weight lignins exhibit good compatibility with polypropylene and show antioxidant activity. The number average molecular weight (Mn) was very low, consequently, polydispersity was very high. The high polydispersity of lignin may cause lower solubility in polymeric materials. ${ }^{25}$ The lower $\mathrm{Mn}$ can be explained by the cleavage of $\beta-\mathrm{O}-4$ linkages by acid hydrolysis during the isolation of dioxane lignin. ${ }^{17}$ It can be stated that the lignin extracted from the mangrove species has higher polydispersity and, consequently, lower solubility in polymeric form than other hardwood lignins. 


\section{${ }^{1}$ H-NMR}

The ${ }^{1} \mathrm{H}-\mathrm{NMR}$ spectra of the acetylated dioxane lignins obtained from the six mangrove species are shown in Figure 3. Subdivisions of the integration curves were made according to Lundquist. ${ }^{26}$ The estimation of the various types of protons per $\mathrm{C}_{9}$ structural unit has been conducted and described elsewhere. ${ }^{13}$ Table 4 shows the subdivisions and distribution of protons

Table 3

Molecular weight of six mangrove species lignins

\begin{tabular}{lccc}
\hline Sample & Mw & Mn & Mw/Mn \\
\hline Sundari & 6,822 & 318 & 21.5 \\
Bine & 11,629 & 438 & 26.5 \\
Keora & 4,469 & 399 & 11.2 \\
Geoa & 7,598 & 363 & 21 \\
Kakra & 8,473 & 355 & 23.9 \\
Pashur & 4,758 & 358 & 13.3 \\
\hline
\end{tabular}

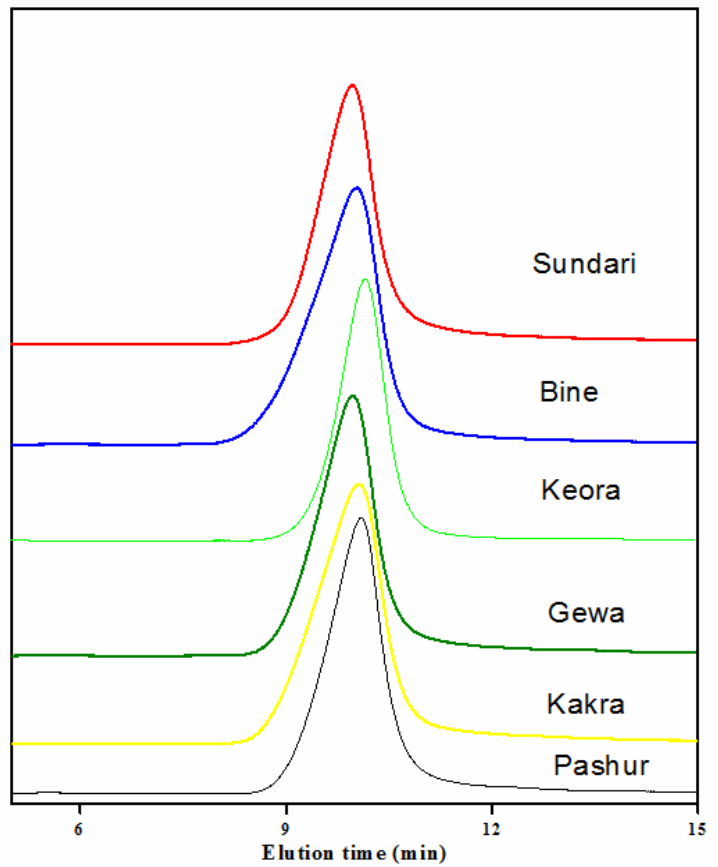

Figure 2: Molecular weight of six mangrove species lignins

As shown in the ${ }^{1} \mathrm{H}$ NMR spectra, higher syringyl propane content of the mangrove species lignin (Fig. 3) can be observed from the relative intensities of the resonances at 6.2-6.8 and 6.8-7.2 ppm, which can be assigned to the aromatic protons in syringyl propane and guaiacyl propane structures, respectively. Among the six mangrove species, keora lignin showed the lowest syringyl propane content. The quantification of the number of syringyl and guaiacyl protons per phenyl found in the present samples. However, strictly quantitative conclusions cannot be drawn regarding the numbers of hydroxyl groups and other protons because of the uncertainty in fixing the boundaries of the resonances and the base lines in the spectra. 


\section{SARWAR JAHAN et al.}

groups, respectively, in the lignin samples. For example, sundri lignin $(1)(\mathrm{x})+(2)(100-\mathrm{x})=$ 133 , where $X=$ no of guaiacyl units. In the same way, it was found that the proportion of guaiacyl to syringyl in sundri was $67 \%$ to $33 \%$. Similarly, the following figures have been found: bine -40 to $60 \%$, keora -55 to $45 \%$, gewa -37 to $63 \%$, kakra -50 to $50 \%$ and pashur -38 to $62 \%$.

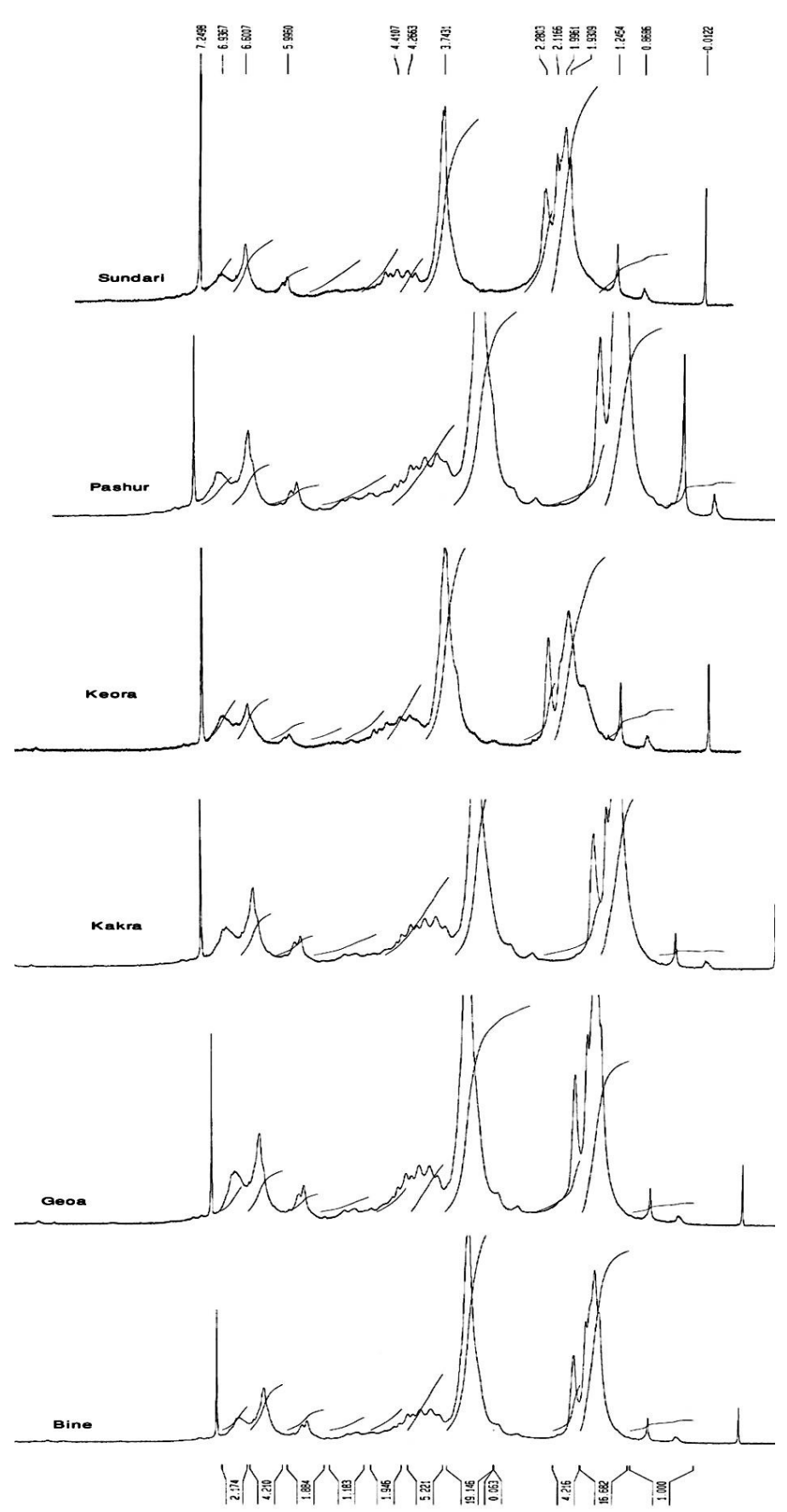

Figure 3: ${ }^{1} \mathrm{H}$ NMR spectra of dioxane lignins extracted from six mangrove species 
Table 4

Assignments of signals and protons per $\mathrm{C}_{9}$ structural unit in the ${ }^{1} \mathrm{H}$ NMR spectra of acetylated lignin of six mangrove species

\begin{tabular}{|c|c|c|c|c|c|c|c|}
\hline \multirow{2}{*}{ Range ppm } & \multirow{2}{*}{ Main assignments } & \multicolumn{6}{|c|}{ Proton per $\mathrm{C}_{9}$ unit } \\
\hline & & Pashur & Bine & Keora & Gewa & Kakra & Sundari \\
\hline $7.25-6.80$ & $\begin{array}{l}\text { Aromatic proton in guaiacyl } \\
\text { units }\end{array}$ & 0.65 & 0.55 & 0.82 & 0.58 & 0.39 & 0.76 \\
\hline $6.80-6.25$ & $\begin{array}{l}\text { Aromatic proton in syringyl } \\
\text { units }\end{array}$ & 0.94 & 1.06 & 0.85 & 0.97 & 0.75 & 1.19 \\
\hline $6.25-5.75$ & $\begin{array}{c}\mathrm{H} \alpha \text { of } \beta-O-4 \text { and } \beta-1 \\
\text { structures }\end{array}$ & 0.46 & 0.47 & 0.35 & 0.41 & 0.38 & 0.57 \\
\hline $4.90-4.30$ & $\mathrm{H} \alpha \& \mathrm{H} \beta$ of $\beta-O-4$ structures & 1.19 & 0.92 & 0.95 & 1.12 & 1.01 & 1.00 \\
\hline $4.30-4.00$ & $\begin{array}{l}\mathrm{H} \alpha \text { of } \beta-\beta \text { structures } \\
\mathrm{H} \text { of xylan residue }\end{array}$ & 0.70 & 1.31 & 1.15 & 0.56 & 0.40 & 0.78 \\
\hline $4.00-3.48$ & $\mathrm{H}$ of methoxyl groups & 4.86 & 4.80 & 4.35 & 4.89 & 3.75 & 3.99 \\
\hline $2.50-2.22$ & $\mathrm{H}$ of aromatic acetates & 1.44 & 1.05 & 1.20 & 1.23 & 0.96 & 1.89 \\
\hline $2.22-1.60$ & $\mathrm{H}$ of aliphatic acetates & 4.17 & 4.17 & 3.87 & 3.57 & 3.69 & 4.74 \\
\hline
\end{tabular}

Considering both aliphatic and aromatic hydroxyls per $\mathrm{C}_{9}$ unit (Table 4), the following calculation could be done: for example, for pashur lignin, the mole ratio $\mathrm{OAc} / \mathrm{OCH}_{3}=(1.44+$ $4.17) / 4.86=1.15$. Thus, the total $\mathrm{OAc} / \mathrm{C} 9$ ratio $=$ $\left(1.62 \mathrm{OCH}_{3}\right) \times\left(1.15 \mathrm{OAc} / 1 \mathrm{OCH}_{3}\right)=1.86$; the number of aliphatic $\mathrm{OAc} / \mathrm{CH}_{3},=\left(1.62 \mathrm{OCH}_{3} / \mathrm{C}_{9}\right)$ $\mathrm{X}\left(4.17 \mathrm{OAc} / 4.86 \mathrm{OCH}_{3}\right)=1.39$ and the number of aromatic $\mathrm{OAc} / \mathrm{CH}_{3},=(1.62) \times(1.44 / 4.86)=$ 0.48 . Therefore, the numbers of aliphatic and the free phenolic hydroxyls of pashur were estimated to be 139 and 48 , respectively, per $100 \mathrm{C}_{9}$ units. Similarly, the numbers of aliphatic and phenolic hydroxyl groups were estimated to be 139 and 35 for bine, 129 and 40 for keora, 119 and 41 for gewa, 148 and 38 for kakra and 158 and 63 for sundri, respectively, per $100 \mathrm{C}_{9}$ units.

The main intermonomeric connections in lignins are aryl glycerol- $\beta-O-4$ aryl ether linkages. ${ }^{26}$ The NMR spectra of the six mangrove species dioxane lignins show that the structural element may contain both erythro and threo configurations due to the presence of the proton at the C- $\alpha$ position of the side chain. The erythro protons $(\mathrm{H} \alpha)$ give a stronger peak at $6.01 \mathrm{ppm}$ than the corresponding peak for the threo form at $\delta 6.09$ in bine, gewa, kakra and sundri lignins, but keora lignin showed almost equal intensity (Fig. $3)$. The proton of the C- $\beta$ and C- $\gamma$ showed a peak at $4.6,{ }^{26}$ and the protons of these six mangrove species lignins were around $0.92-1.19 / \mathrm{C}_{9}$.

\section{CONCLUSION}

The syringyl to guaiacyl ratios of the six mangrove species lignins investigated here were higher than in the case of other hardwoods. The polydispersity of these lignins was very high, which indicated lower solubility. The structural element contained both erythro and threo configurations due to the presence of the proton at the C- $\alpha$ position of the side chain. The erythro protons $(\mathrm{H} \alpha)$ gave a stronger peak at $6.01 \mathrm{ppm}$ than the corresponding peak for the threo form at $\delta 6.09$ in bine, gewa, kakra and sundri lignins, but keora lignin showed almost equal intensity.

\section{REFERENCES}

1 C. Giri, B. Pengra, Z. Zhu, A. Singh and L. L. Tieszen, Estuar. Coast. Shelf Sci., 73, 91 (2007), https://doi.org/10.1016/j.ecss.2006.12.019

${ }^{2}$ E. Mansyur and Y. Soegiarti Elly, Berita Selulosa, 10, 37 (1974).

${ }^{3}$ D. H. Miles, U. Kokpol, V. Chittawong, S. TipPyang, K. Tunsuwan et al., IUPAC, 70, 1 (1999).

${ }^{4}$ M. M. Singh, R. Chopra and B. G. Karira, IPPTA J., 18, 1 (1981).

5 S. P. Mun, M. S. Jahan, A. Al-Maruf and D. Chowdhury, Wood Sci. Technol., 45, 281 (2011), DOI: 10.1007/s00226-010-0333-7

${ }^{6}$ A. Al-Maruf and M. S. Jahan, J. Indian Acad. Wood Sci., 12, 116 (2015), DOI: 10.1007/s13196-018-0204-7

7 K. V. Sarkanen and C. H. Ludwig, "Lignins. Occurrence, Formation, Structure, and Reactions", New York, Wiley-Interscience, 1971. 


\section{SARWAR JAHAN et al.}

${ }^{8}$ F. S. Chakar and A. J. Ragauskas, Ind. Crop. Prod., 20 , 131

https://doi.org/10.1016/j.indcrop.2004.04.016

${ }^{9}$ K. K. Pandey, J. Appl. Polym. Sci., 71, 1969 (1999), https://doi.org/10.1002/(SICI)1097-

4628(19990321)71:12<1969::AID-APP6>3.0.CO;2-D

${ }^{10}$ I. Kilpelaeinen, J. Sipilae, G. Brunow, K. Lundquist and R. M. Ede, J. Agric. Food Chem., 42, 2790 (1994), https://doi.org/10.1021/jf00048a026

11 D. V. Evtuguin, C. P. Neto, A. M. Silva, P. M. Domingues, F. M. Amado et al., J. Agric. Food Chem., 49, 4252 (2001), https://doi.org/10.1021/jf010315d

12 L. Oliveira, D. V. Evtuguin, N. Cordeiro, A. J. Silvestre, A. M. Silva et al., J. Agric. Food Chem., 54, 2598 (2006), https://doi.org/10.1021/jf0528310

${ }^{13}$ M. S. Jahan and S. P. Mun, J. Wood Chem. Technol., 27, 83

(2007), https://doi.org/10.1080/02773810701486865

${ }^{14}$ M. S. Jahan and S. P. Mun, Bangladesh J. Sci. Ind. Res., 44, 271 (2010), https://doi.org/10.3329/bjsir.v44i3.4399

15 M. S. Jahan and S. P. Mun, Cellulose Chem. Technol., 40, 457 (2006).

${ }^{16}$ G. Gellerstedt, J. Pranda and E.-L. Lindfors, J. Wood Chem. Technol., 14, 467 (1994).
${ }^{17}$ A. M. Seca, J. A. Cavaleiro, F. M. Domingues, A. J. Silvestre, D. V. Evtuguin et al., J. Agric. Food Chem., 48, 817 (2000), DOI: 10.1021/jf9910988

${ }^{18}$ D. Fengel and G. Wegener (Eds.), "Wood: Chemistry, Ultrastructure, Reactions", Berlin, Walter de Gruyter, 1984, pp. 132-174.

${ }^{19}$ R. Sun, J. Tomkinson, X. F. Sun and N. J. Wang, Polymer, 41, 8409 (2000), https://doi.org/10.1016/S0032-3861(00)00190-7

20 O. Faix, Holzforschung, 45 (Suppl.), 21 (1991), https://doi.org/10.1515/hfsg.1991.45.s1.21

${ }^{21}$ M. Sain and S. Panthapulakkal, Ind. Crop. Prod., 23, 1 (2006), https://doi.org/10.1016/j.indcrop.2005.01.006

${ }^{22}$ K. V. Sarkanen, H.-M. Chang and G. G. Allan, Tappi J., 50, 583 (1967).

${ }^{23}$ E. Sjostrom, "Wood Chemistry: Fundamentals and Applications", USA, Academic Press, 2013, p. 89.

${ }^{24}$ C. Pouteau, P. Dole, B. Cathala, L. Averous and N. Boquillon, Polym. Degrad. Stabil., 81, 9 (2003), oi:10.1016/S0141-3910(03)00057-0

${ }^{25}$ V. P. Saraf and W. G. Glasser, J. Appl. Polym. Sci., 29, 1831 (1984),

https://doi.org/10.1002/app.1984.070290534

${ }^{26}$ K. Lundquist, Acta Chem. Scand. B, 33, 27 (1979), http://actachemscand.org/pdf/acta_vol_33b_p0027-

0030.pdf 